\title{
Migration and ethnic group disproportionality in special education: an exploratory study
}

Susan L. Gabel ${ }^{\mathrm{a}, \mathrm{b} *}$, Svjetlana Curcic ${ }^{\mathrm{b}}$, Justin J.W. Powell ${ }^{\mathrm{c}}$, Khaled Khader $^{\mathrm{a}}$ and Lynn Albee ${ }^{\mathrm{a}}$

${ }^{a}$ Disability and Equity in Education Program; ${ }^{b}$ Special Education, National Louis University, Chicago, USA; ${ }^{c}$ Social Science Research Center, Berlin, Germany

(Received 1 August 2008; final version received 28 January 2009)

Issues of educational equity and opportunity cannot be understood without regard to special education, as a key response to disabilities, disadvantages, and difficulties. Likewise, globalization cannot be understood without regard to crossborder migration and minority group status in society. Illuminating the nexus of these, research into disproportionality in special education, defined as the over- or under-representation of particular ethnic groups in such programs, shows that this, too, has become a global phenomenon. Comparing Canada, Germany, New Zealand and the USA, this article explores international trends in migration and discusses the globalization of ethnic group disproportionality - as a primary indicator of inequity in education. We conclude by questioning the functions of special education in an era of globalization and identifying the challenges ahead that these findings indicate.

Keywords: special education; disproportionality; globalization, ethnicity; Canada; Germany; New Zealand; USA

\section{Introduction}

Special education is a key response to disabilities, disadvantages and difficulties in education and thus important in understanding issues of educational inequity. Globalization, or the interconnectedness and homogenization of conditions, cannot be understood without regard to cross-border migration, which results in shifting minority status in societies around the world. At the nexus of special education and globalization is disproportionality, defined as the over- or under-representation of particular ethnic groups in such programs. Empirical disproportionality findings from Canada, Germany, New Zealand and the USA presented here serve as a primary indicator of inequity in education.

\section{Globalization}

Globalization is often understood as the increasing interconnectedness of production, communication and technology, creating a tendency toward homogenization of international economic and cultural conditions. This process presents disabled people with a complex set of multilayered opportunities, such as the diffusion of disability rights

*Corresponding author. Email: SGabel@nl.edu 
and enhanced access to schooling. However, globalization also presents a number of challenges, including increased polarization in labour markets. In this article we focus on challenges, particularly those noted by Drilik's $(1999,302)$ claim that 'the euphoria over globalisation ... has served to disguise the very real social and economic inequalities that are not merely leftovers from the past, but are products of the new developments'. In particular, Drilik is concerned about the possibility that globalization is another form of modernity driven by the hegemony of capitalism and resulting in the 'marginalisation of the majority of the world's population' (p. 304). In fact, globalization as a process of social change not only implies the free movement of capital and information, but also migration flows due to displacement and deterritorialization (Suárez-Orozco 2001).

The research agenda on migration and education focuses on the ways immigrant children have limited symbolic and material resources to support their learning progress (Gibson and Rojas 2006, 73), while research in disability studies in education emphasizes the structural and cultural barriers that disable students. At the nexus of disability and immigration lie institutional responses that attempt to assimilate or colonialize groups by pathologizing differences and treating them with special education interventions. Since the nexus represents both current inequities (segregation of particular student groups) and new developments (use of special education to assimilate immigrant students) it is a good example of the consequences of what Drilik (1999) argued was political marginalization 'in the midst of spreading democracy' (304), something Papastephanou $(2005,534)$ described as the 'material effects of globalisation'. 'Globalisation often becomes an ideological device', argued Papastephanou, 'that states and governments employ as an excuse for imposing certain policies that would otherwise fail to gain public acceptance or support' (Papastephanou 2005). We accept the premise that globalization is occurring in the following ways in relation to education: (1) there is an international consensus about the importance of 'education for all' (UNESCO 1990, 1994, 1999, 2000); (2) the World Bank and multinational corporations are driving many of the national educational reforms in response to Education for All and the Salamanca Statement (UNESCO 2002; Peters 2004; Tamatea 2005); (3) Euro-American centered discourses pervade international education reforms (Goldstein 2004; Barton and Armstrong 2007; Alur 2007; Tamatea 2005). The second and third points reflect both Drilik's and our concerns about globalization. In a globalized world schools prepare people to participate in the dominant production model, which often enlarges instead of reduces the gap between rich and poor. Throughout the world economic, social and cultural barriers constrain the poorest social groups - including disabled people - to achieve their educational and employment goals.

Considering Drilik's proposition that discourses of globalization can mask the fact that structural inequities remain intact, we next look at migration statistics. After a brief look at migration data we explore the global phenomenon of disproportionality in special education.

\section{Immigration}

Fifteen years ago Stewart $(1993,1)$ claimed that 'the world's people are on the move in one of the most massive population shifts in history'. He predicted that global migration would only increase during the 21 st century, with significant implications for both the sending and receiving nations. This article addresses the challenges of 
immigration and globalization in the 21 st century and how these challenges could affect disabled people, especially given the continuing - rising - importance of education for social, economic and political participation. In 2005, the latest year for which statistics are available, 3\% (191 million) of the people in the world lived outside their country of birth. Sixty percent of immigrants resided in developed areas of Europe, Asia and North America. Seventy-five percent of all immigrants were concentrated in 28 countries, one in every 10 persons living in these regions was an immigrant and one in five immigrants lived in the USA. From 1996 to 2005 the proportion of countries aiming to lower migration fell from $60 \%$ to $12 \%$ (United Nations 2006), indicating an increased interest in migration, particularly in terms of how it can help meet national needs for skilled labor and scientific and technological expertise. We focus in this study on some implications of migration for disabled as well as non-disabled migrants.

\section{Disproportionality: under- and over-representation}

One dimension of increased concerns about educational equity in an increasingly interconnected world is disproportionality in special education, specifically as it is related to ethnic minority groups and migration patterns. The worldwide evidence of the disproportionality of subjugated groups suggests that whilst the causes of overrepresentation in each country may differ, there are global patterns that beg to be explored. Thus, we began by asking: (1) where has ethnic group disproportionality in special education been documented; (2) what are the comparative conditions? We use disproportionality as did Dyson and Gallannaugh (2008), to refer to the identification of students as disabled resulting in students from some social groups being assigned special education labels in proportions higher or lower than expected based on the overall ratio, or risk ratio, of the particular group within the overall student body. Disproportionality subsumes both under- and over-representation. While many studies indicate that gender is a factor in disproportionality (boys are usually ove-represented) (see Wehmeyer and Schwartz 2001), our interest in globalization and migratory patterns leads us to focus on over-representation of students who are members of racial or ethnic minority groups. Poverty has powerful negative effects on educational opportunity; however, the bundle of factors affecting the relationship between poverty, equal opportunity, achievement and a special education classification require further disentangling (Skiba et al. 2006, 1446) than we are able to do here.

Most examples of disproportionality in disability categories are found not in low incidence categories (such as deafness or blindness), but rather among high incidence categories, such as learning disability or behavioral difficulties, that rely on subjective evaluations of students and school and community contextual factors rather than biological bases (MacMillan and Reschly 1998). While each country has its own set of policies, categories and eligibility requirements that challenge precise crossnational comparisons, here we explore some general comparisons that can be made to illuminate the relationship between globalization and disproportionality in special education.

Large differences between ethnic groups are often related to socio-economic characteristics, age shifts in the population, immigration policies or differences in linguistic competencies, cultural expectations and life experiences. Other factors include lack of knowledge of different types of schooling or parental rights, experiences with education in the country of origin and individual migration experiences. Powell 
(2006) outlined these differences in detail, noting that 'across Europe, the rates of all children classified and receiving services vary considerably, from less than one percent to nearly a fifth of all students' (p. 580). He further observed that special education eligibility criteria vary widely, as do the students served, who are ethnically, linguistically and economically diverse. Although these factors compound the difficulty of comparative research, we believe cross-national analyses offer considerable opportunities to understand the variable impact of global phenomena and to test hypotheses about worldwide trends and national specificities.

In their study of disproportionality in England Dyson and Gallannaugh (2008) recognized the above factors, but countered that the problem 'is not the misidentification of minority students as disabled, but the misleading identification of them as having "special educational needs" as individuals when the difficulties they experience are systemic and structural in origin' (p. 38, emphasis added). This is the crux of our concern and one that is connected to Drilik's claim about globalization, raising questions as to the functions of special education. When it comes to immigration and misleading identification, what function does special education serve, particularly in an increasingly globalized world? What are the implications of these patterns of disproportionality for disabled students, whether or not they are immigrants? We return to this issue later.

\section{Documenting disproportionality}

A review of the international literature on disproportionality in special education indicates that we are facing a global dilemma about 'effective service provision for ethnic minority and indigenous learners with special needs' (Bevan-Brown 2006, 221). In the USA African American students are over-represented in many special education categories, too often the result of misidentification of disability (Blanchett 2006; Coutinho and Oswald 2000; Ferri and Connor 2005a, 2005b; Hosp and Reschly 2004; Losen and Orfield 2002). While some researchers argue that this is an artifact of racism (see, for example, Ferri and Connor 2005a, 2005b), others have claimed that poverty, poor parenting and the devaluing of education (Herrnstein and Murray 1994) or cultural and economic disadvantage (Pearl 1997) lead to impairments that necessitate special education. In New Zealand Māori and Pasifika students are over-represented (Brown and Wills 2000; Matheson 2006; New Zealand Council for Educational Research 2000; New Zealand Ministry of Health 2004). In Canada Native Americans and members of other indigenous groups are over-represented (Indian and Northern Affairs Canada 2004; Mattson and Caffrey 2001; Silver et al. 2002). In Germany Italian, Portuguese, Turkish, Greek, Spanish and ex-Yugoslavian students are over-represented, whereas other immigrant groups are under-represented (Wagner and Powell 2003). In the UK Afro-Caribbean students are over-represented while, interestingly, African students are not (Bevan-Brown 2006). Roma students are over-represented in the UK (Dyson and Gallannaugh 2008), Czech Republic, Bulgaria, Hungary and Romania (European Roma Rights Centre 2007a, 2007b; Open Society Institute 2005). In Japan the Burakumin ('hamlet people', with ancestors who worked in certain 'unclean' occupations, such as gravediggers, butchers or tanners) are over-represented (Gelb and Mizokawa 1986). While these examples clearly do not provide an exhaustive list, they do indicate a global pattern that deserves enhanced research attention.

After reviewing the international literature on disproportionality, we targeted four countries for this study: New Zealand, Canada, the USA and Germany. Our choice of target countries has been determined by several factors, including our decision to use 
quantitative data that are available, reliable and from verifiable official sources and from countries that have highly institutionalized special education systems. We are able to report national data on three of the four countries, but data limitations led us to study one province for Canada, British Columbia (as have major cross-national studies, e.g. OECD 2004). While our review of the literature uncovered a significant number of publications that made claims about disproportionality, in many cases attempts to locate reliable empirical data about the phenomenon proved fruitless or ended without sufficient data to support the claim.

\section{New Zealand}

Over-representation affects indigenous populations in New Zealand, Canada and the USA. The earliest inhabitants of New Zealand were the Māori, who migrated to the islands in the 14th century. The latter half of the 18th century brought British and French explorers and by 1840 the Treaty of Waitangi marked the official colonization of New Zealand, at which time the Māori were subjugated to the Queen of England.

Today New Zealand is a country of 4.25 million people, of whom $77 \%$ are of European descent, 14.6\% are Māori (indigenous New Zealanders) and 6.9\% are Pasifika (immigrants from other Pacific islands). Nine out of ten Māori live on the North Island and almost half of all Māori are under 25, indicating significant implications for schools on the North Island. From 1991 to 2001 the Māori population increased 21\% (Statistics New Zealand 2008). In 2001 the number of Māori students increased by more than $3 \%$ and Pasifika students increased by $4 \%$, while the number of Pakeha (European) students decreased by under 1\% (Matheson 2006; New Zealand Ministry of Education 2003). Fifteen percent of Māori children aged 0-14 living in households are disabled, whereas the disability rate for the non-Māori population aged 0-14 is 10\% (New Zealand Ministry of Health 2004). Furthermore, Māori boys were more likely to have a disability than Māori girls (16\%, compared with 13\%) (New Zealand Ministry of Health 2004).

Immigration into New Zealand is carefully controlled to meet the labor needs of the country. In 2006-2007 the largest sources of sponsored immigration (which usually means seeking permission for family members to migrate) were the UK $(17 \%)$, China (17\%) and India (16\%). The largest numbers of immigrants from Oceania were Samoan and Tongan, although immigrants from these islands have decreased since 1980 while those from Europe and Asia have increased. Pacific island immigrants are classified as Pasifika in government reports. From 1979 to 2007 the percentage of New Zealanders who have left the country has far outpaced the percentage that have returned, while the percentage of non-New Zealanders who have arrived outpaced those who have left (New Zealand Department of Labour 2008).

Disproportionality in special education in New Zealand has been well documented by Massey University's (2000) survey of over 1500 schools responding to the policy initiatives of Special Education 2000 (New Zealand Ministry of Education 1995), New Zealand's large-scale school reform legislation aimed at equalizing education for disabled students. Students in the high to very high needs category receive support services from the Specialist Education Services, a separate unit providing ongoing individualized funding and services. This unit also provides services under the Severe Behaviour Initiative, a major component of Special Education 2000 and in which many Māori students are found. In the most recent data available Māori students were 
Table 1. Percentage of students of specific ethnic groups in each special education category compared with the percentage of the ethnic groups in the total student population (New Zealand, 1999-2000).

\begin{tabular}{lccc}
\hline & \multicolumn{3}{c}{ Percentage } \\
\cline { 2 - 4 } Ethnic group & $\begin{array}{c}\text { In total student } \\
\text { population }\end{array}$ & $\begin{array}{c}\text { In high to very high } \\
\text { needs category }\end{array}$ & $\begin{array}{c}\text { In moderate needs } \\
\text { category }\end{array}$ \\
\hline Māori & $21.6 \%$ & $20 \%$ & $35 \%$ \\
Pasifika & $8.8 \%$ & $9 \%$ & $11 \%$ \\
Pakeha & $59.6 \%$ & $64 \%$ & $45 \%$ \\
\hline
\end{tabular}

Sources: Massey University (2000) and Matheson (2006).

over-represented in the moderate needs category - a category for which subjective judgment is often required for diagnosis - while Pakeha students are under-represented (see Table 1).

In addition to the data on over-representation, suspension rates can provide a lens through which to analyze systemic inequities, and the data for New Zealand are disturbing. In the New Zealand context suspension refers to exclusion from school for a period determined by the school board of trustees. Māori students are three times more likely to be suspended than are Pakeha students. Pasifika students are slightly more likely to be suspended than are Pakeha students, but their suspensions have increased in recent years (Matheson 2006; New Zealand Ministry of Education 2006), despite their decreased immigration rates. Rather than providing Māori special education students with interventions that support academic achievement, Bevan-Brown $(2006,222)$ reported that such services range from inadequate to sometimes being excluded altogether.

\section{Canada (British Columbia)}

Some striking similarities exist between New Zealand and Canada. Much like the New Zealand indigenous population, the Canadian aboriginal population, also referred to as First Nations (Assembly of First Nations, n.d.), increased 22\% between 1996 and 2001, when half of all aboriginals were under 25 years of age (Canadian Government 2001). On the other hand, the indigenous percentage of the total population is smaller in Canada, where the breakdown is 66\% European and 2\% (1.3 million) aboriginal (i.e. First Nation or Native American, Inuit and Métis) (US Government 2007). We have not found reliable national data on over-representation in Canada, but focus instead on the province of British Columbia, with one of the highest populations of aboriginals in the country, at 7.9\% (Ministry of Education, Province of British Columbia 2002). We find significant over-representation for this group in British Columbia for the academic year 2000-2001 (see Table 2). During the previous school year aboriginal students represented $7.2 \%$ of the severe behavior category, therefore, the table shows a rise in aboriginal representation in that category. It is also significant to note that less than $5 \%$ of aboriginal students in Grades $\mathrm{K}-3$ were assigned to the behavior category, but by Grades 8-10 15\% were identified as having behavior disorders, a marked increase that deserves further investigation. According to the Ministry of Education, Province of British Columbia (2001, 2002) aboriginal students are almost four times more likely to be assigned to the severe behavior category $(3.5 \%)$ 
Table 2. Students of specific ethnic groups assigned to special education categories compared to percentage of the ethnic groups in the total student population (British Columbia, 2000-2001).

\begin{tabular}{lcccc}
\hline & \multicolumn{4}{c}{ Percentage } \\
\cline { 2 - 5 } Ethnic group & $\begin{array}{c}\text { In total student } \\
\text { population }\end{array}$ & $\begin{array}{c}\text { In behaviour } \\
\text { category }\end{array}$ & $\begin{array}{c}\text { In severe learning } \\
\text { disability category }\end{array}$ & $\begin{array}{c}\text { In gifted } \\
\text { category }\end{array}$ \\
\hline Aboriginal & $7.2 \%$ & $9.4 \%$ & $4.5 \%$ & $<1 \%$ \\
Non-aboriginal & $92.8 \%$ & $<3 \%$ & $2.3 \%$ & $3 \%$ \\
\hline
\end{tabular}

Sources: Ministry of Education, Province of British Columbia $(2001,2002)$ and McBride and McKee (2001).

than are non-aboriginal students (0.5\%) (McBride and McKee 2001), but are underrepresented in the gifted category.

During the year represented in Table 2 British Columbia had the second highest immigration rate after Ontario. In 2000 the nationwide poverty rate among immigrant children was slightly higher than the $40 \%$ poverty rate of aboriginals and over twice that of all children 0-14 years of age (Canadian Government 2003). In 2000 the percentage of immigrants from developing countries was higher than those from developed countries and the rate far outpaced that from developed countries, by a factor of three. As in New Zealand, in Canada from 1950 to 2000 the immigrant population growth rate has steadily increased, while the non-immigrant population growth rate has steadily decreased (Canadian Government 2008).

\section{$\boldsymbol{U S A}$}

The 2000 census in the USA (where ethnic and racial categories are self-defined and individuals can be members of multiple categories) showed that $81 \%$ of the population was White (i.e. primarily of European origin). Native Americans and Native Alaskans composed the indigenous population at $1.53 \%$ of the total population, African Americans represent $12.7 \%$ of the population and Hispanics represent $12.5 \%$ of the population (three-quarters of whom are from Mexico) (US Census Bureau 2006a, 2006b). The data on Hispanics suggest a similar but much stronger upward trend in the proportion of the overall population to that of New Zealand's Māoris and Canada's aboriginals - by 2030 it is predicted that $20.1 \%$ of the population will be Hispanic and the school age population is already at that level. Yet, in contrast to indigenous populations in New Zealand and Canada, 40\% of Hispanics in the USA are foreign born (US Government 2007). The US Department of Education's (2006, 2007) data show that in 2004 and 2005 Native American/Native Alaskan students were the most over-represented group.Yet nationally aggregated data for Native American/Native Alaskan disproportionality is misleading, since these students are concentrated in specific regions of the country, so we present their data in a separate table (Table 3) across states with the highest concentration of Native American/ Native Alaskan residents: Arizona (12.6\% of state population), Oklahoma (12.4\%), California (12.2\%) and New Mexico (8.1\%) (US Census Bureau 2007). We also include Alaska.

While African American students are over-represented in special education overall, Hispanic students are under-represented, although there is regional variation (Table 4). Data disaggregated by state or region exhibit larger disparities (see Losen 
Table 3. Percentage of Native American/Native Alaskan students receiving special education in states with high concentrations of ethnic group (USA, 2004-2005).

\begin{tabular}{lccc}
\hline & \multicolumn{3}{c}{ Percentage Native American/Native Alaskan } \\
\cline { 2 - 4 } & & \multicolumn{2}{c}{$\begin{array}{c}\text { Receiving special education of all special education } \\
\text { students (6-21) }\end{array}$} \\
\cline { 3 - 4 } State & In total state population & 2004 & 2005 \\
\hline Alaska & 3.8 & 33.25 & 34.41 \\
Arizona & 12.6 & 7.92 & 7.87 \\
California & 12.2 & 0.93 & 0.90 \\
New Mexico & 8.1 & 12.55 & 12.29 \\
Oklahoma & 12.4 & 16.59 & 17.23 \\
\hline
\end{tabular}

Sources: US Department of Education (2006) and US Census Bureau (2007).

and Orfield 2002; Coutinho and Oswald 2000). As in New Zealand and Canada, minority students face inequity in special education services and in opportunities for employment after high school in the USA as well. For example, after completing high school 75\% of African American youth with disabilities, as opposed to 47\% of White students, are unemployed (Losen and Orfield 2002).

We focus next on the data for Hispanic students, who have been the target of a conflict over undocumented immigration that heated up during the 1990s when antiimmigration groups proposed that the children of undocumented immigrants be prevented from attending public schools. While national data indicate that Hispanic students are not over-represented in special education, recent studies suggest that they are over-represented in school districts where there are a large number of Spanish speaking students (Artiles et al. 2005), although it is still unclear which factors - first language proficiency, poverty, first language literacy, educator bias and/or inequitable opportunity - most influence these special education decisions and why these students are over-represented where they attend school in large numbers. Artiles and Klingner $(2006,2188)$ noted that 'preliminary evidence suggests that a disproportionate number of ELLs [English language learners] are being placed in special education', particularly when educators believe they lack proficiency in either the first or second language. As Artiles et al. (2005) pointed out, 'educators, particularly special educators, have a bias toward accounting for within-child factors (e.g. cognitive deficits) when explaining learning difficulties', rather than accounting for structural inequity and the 'dilemma of difference' (Minow 1990; Artiles 1998).

If the USA case contrasts immigrant groups who arrived across a span of several hundred years, the German case exemplifies the impact of large migratory flows over the past few decades.

\section{Germany}

Considerable immigration from Southern and Eastern Europe into West Germany occurred over the post-World War II period, whereas ethnic minorities are a small group in the Eastern German states (less than $1 \%$ of the school age population). After reunification in 1990 around one in ten students did not have a German passport. In terms of overall educational participation rates, the number of non-German students 
Table 4. Percentage of students in each racial group receiving special education by race compared with the percentage in the total student population (USA, 2004).

\begin{tabular}{lccc}
\hline & \multicolumn{3}{c}{ Percentage in racial group } \\
\cline { 2 - 4 } & $\begin{array}{c}\text { In total student } \\
\text { population (5-19) }\end{array}$ & $\begin{array}{c}\text { Receiving special education of all special } \\
\text { education students (6-21) }\end{array}$ \\
\cline { 2 - 4 } Racial group & 2006 & 2004 & 2005 \\
\hline African American & 16.9 & 20.75 & 20.66 \\
White & 55.9 & 59.50 & 58.96 \\
Hispanic & $20.5^{\text {a }}$ & 16.15 & 16.71 \\
\hline
\end{tabular}

Sources: US Department of Education (2006, 2007) and Center for Public Education (2008).

${ }^{a}$ Actual percentage might be higher since many Hispanics are undocumented immigrants and may avoid reporting to the authorities.

in all German general (non-vocational) schools rose from 8.8\% in 1991-1992 to 10\% in 2003-2004 (Statistisches Bundesamt 2005). A similar development occurred in the special school sector. In 1970 Germany registered only 3900 special school students who were not of German nationality, but in 2005 there were 65,600; since the mid 1960 s the absolute number of non-German special school students has increased more than 20 -fold. Although their percentage of the total school population in 1999 was only $9.4 \%$, almost $15 \%$ of all students in special schools were not German (Statistisches Bundesamt 2002).

Children and youth from the main post-World War II emigration countries all had a higher relative risk of attending a special school than did Germans: Italy (2 times as likely to be in special schools than Germans), Portugal (1.64), Turkey (1.53), Greece (1.25) and Spain (1.20). While children and youths growing up in families from the war-torn regions of the Balkans, such as Serbia and Montenegro (3.42) or Macedonia (1.61), Bosnia and Herzegovina (1.38) had higher relative risks of being segregated, Croatian nationals were just as likely to attend special and general schools (1.00) (see Table 5). German children and youth were under-represented in special schools (relative risk 0.93). A significant group not differentiated in these official statistics are ethnic Germans from Eastern Europe (Aussiedler), who came to Germany en masse after reunification and automatically received German citizenship. Benefiting from favorable integration policies, their educational attainments are also facilitated by more highly educated parents than many other immigrant groups and especially language-based incorporation processes, although very few spoke German fluently upon arrival (Söhn 2008).

Children without German citizenship, even if they were born in Germany, are clearly over-represented in special schools and the trend is going up, not down. However, once again, differentiation of the overall group is necessary to understand the situation for non-German individuals and subgroups. Two-thirds of non-German students attending special schools were classified as having a 'learning disability', while the proportion of German students classified in that category has declined from four-fifths in the 1970s to about half today, increasing that main category's 'ethnic' or non-German constituency (Wagner and Powell 2003). In contrast to the definition of 'learning disability' in the USA as a discrepancy between tested IQ and performance, in Germany this category is defined primarily by low socio-economic status and 


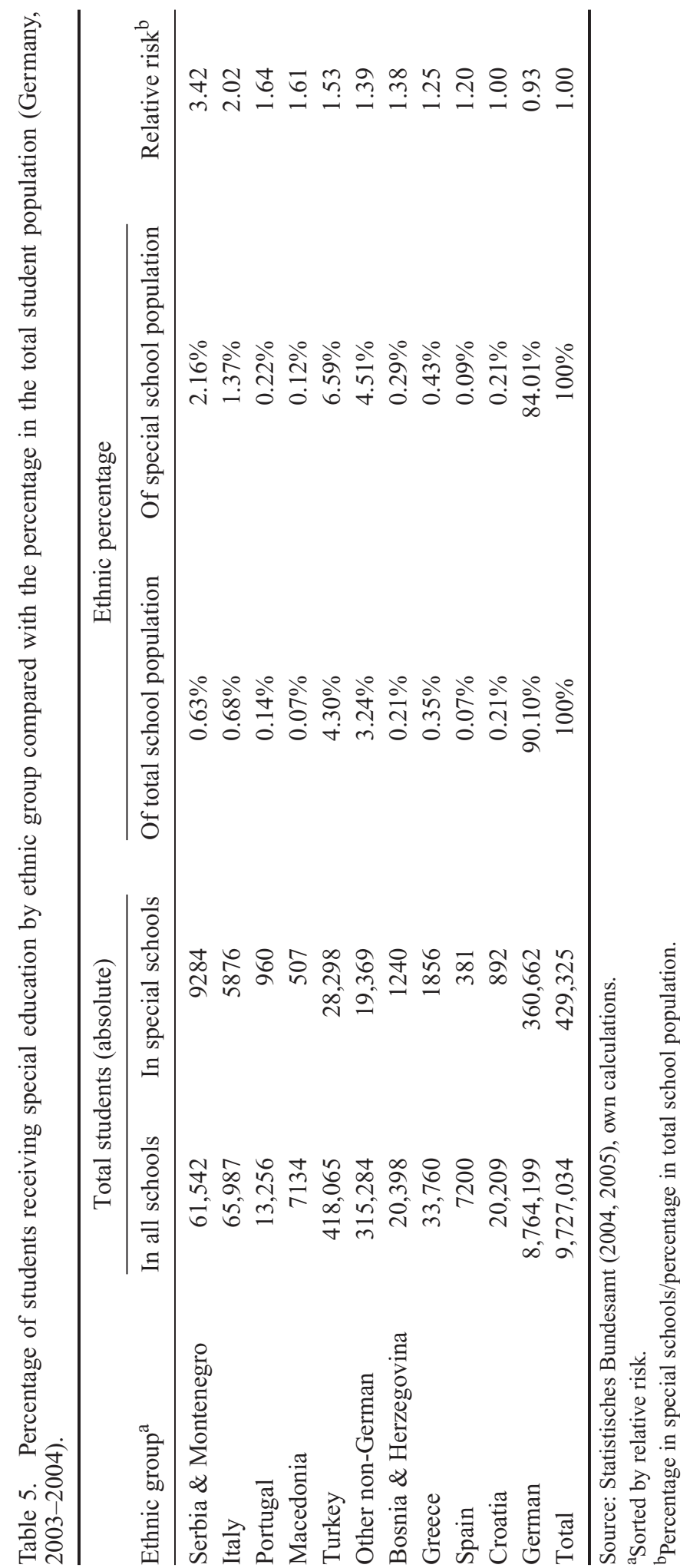


legitimately securing these disadvantaged students additional resources, albeit in segregated settings (see Powell 2009 for further German-American differences).

Called 'the prerequisite' for integration (Katzenbach de Ramírez 1997, 6), linguistic competency is often lacking in non-German students and thus taken to be responsible for school failure. Language difficulties often lead to transfer to special schools, which has not been shown to be particularly effective in assisting non-German youth in learning German and enhancing their school performance. In fact, the opposite is the case: special schools are the school type in which the least training occurs in a language other than German (Statistisches Bundesamt 2001, 68). Non-native speakers are at risk of being selected and allocated early in their school careers to segregated settings, although the risk depends largely on the state (Land) and locality in which they live. Student bodies of special school systems do not reflect the composition of the general educational system in a linear relationship. Rather, their students are more often male, non-German and of lower socio-economic status (Wagner and Powell 2003). Further research should focus on the migration experiences, language competencies and socio-economic status of non-Germans to disentangle these effects on classification and allocation rates.

\section{Similar challenges ahead}

This exploratory study comparing four countries has given us some insight into disproportionality as a global phenomenon. It has also revealed complex relationships between educational inequities, the function of special education and ethnic minority groups around the world. If solutions are to be found for the continued over-representation of certain ethnic groups a need for further research, international networking, shared political action and global perspectives is clear. However, we agree with Barton and Armstrong (2007), who reminded us that 'we cannot underestimate the importance of recognising the particularities, as well as the commonalities' since we cannot assume 'that meanings will be shared across cultures - or even within the same national context or education authority'. Indeed, global perspectives must mediate local meanings and shared political actions should support local agendas.

Our study has shown that in New Zealand, Canada, the USA and Germany, indigenous and immigrant population rates tend to be rising while white, non-immigrant population rates are falling or remain stable. Furthermore, indigenous and immigrant populations tend to be younger overall than white, non-immigrant populations, thus placing even greater emphasis on issues of educational equity and opportunity. These countries also show that transmigration increases language, cultural and other differences that increase within-country heterogeneity. Along with disabled people as a whole, ethnic groups that have higher rates of classification into special education have poor educational outcomes and are economically disadvantaged. Together these factors increase the challenges facing schools and society. The unwillingness or inability of governments to respond to the challenges of globalization with effective policies and programs reduces the opportunities available to indigenous, immigrant and disabled people. If 'education for all' and special education have become ubiquitous throughout the world, the global phenomenon of disproportionality questions how much progress has been made in achieving educational equity.

As Alur $(2007,98)$ pointed out, 'colonialism may have officially come to an end but a new era of neo colonialism has taken over. ... One legacy of colonialism is a deeply entrenched belief that "West is best", Since the 'West is best' mindset is the 
kind of thinking that has created the globalization of disproportionality, we propose that the solutions will need to opt for a premise that produces equitable educational outcomes and that questions the colonialist function of special education.

Earlier we proposed that special education serves multiple functions when it comes to misleading identification as ethnic group membership is translated into student disability. In the globalized world special education not only segregates disabled people, it disables indigenous and immigrant people, causing their educational careers and socio-educational conditions to mirror those of disabled people. The challenge of the integration of minority ethnic groups into society remains ... as it does for disabled people. In the case of immigrant and indigenous students special education is employed as a tool for assimilation into the dominant society but functions as a tool of exclusion from the dominant society. The result is the alienation of immigrant children from their new homeland and an additional barrier faced by indigenous and disabled children as they attempt to participate fully in their native lands. Even in comparably well-off Europe ethnic minorities generally have low levels of education, language difficulties, high drop-out rates from school, and higher rates of un- or under-employment (Minority Rights Group International 2006). Such findings speak to the 'material effects of globalisation' (Papastephanou 2005, 534).

Finally, the evidence presented here indicates the need for further inquiry into the disjunction between the ostensible purposes of special education, the way it is used by educators and its actual function. Disproportionality in special education as a global phenomenon is intricately connected to broader social issues, such as socio-economic status and disadvantage, labor market integration and social inclusion.

\section{References}

Alur, M. 2007. The lethargy of a nation: Inclusive education in India. In Policy, experience and change: Cross-cultural reflections on inclusive education, ed. L. Barton and F. Armstrong, 91-106. Dordrecht, The Netherlands: Springer.

Artiles, A.J. 1998. The dilemma of difference: Enriching the disproportionality discourse with theory and context. The Journal of Special Education 31, no. 1: 32-6.

Artiles, A.J., and J.K. Klingner. 2006. Forging a knowledge base on English language learner with special needs: Theoretical, population, and technical issues. Teachers College Record 108, no. 11: 2187-94.

Artiles, A.J., R. Rueda, J. Salazar, and I. Higareda. 2005. Within-group diversity in minority disproportionate representation: English language learners in urban school districts. Exceptional Children 71: 283-300.

Assembly of First Nations. n.d. A declaration of First Nations. Assembly of First Nations. http://www.afn.ca/article.asp?id=52.

Barton, L., and F. Armstrong. 2007. Introduction. In Policy, experience and change: Crosscultural reflections on inclusive education, ed. L. Barton and F. Armstrong, 1-4. Dordrecht, The Netherlands: Springer.

Bevan-Brown, J. 2006. Beyond policy and good intentions. International Journal of Inclusive Education 10, nos. 2-3: 221-34.

Blanchett, W.J. 2006. Disproportionate representation of African American students in special education: Acknowledging the role of White privilege and racism. Educational Researcher 35, no. 6: 24-8.

Brown, C., and R. Wills. 2000. Special education 2000 - Getting it right together? Paper presented at the International Special Education Congress, July 24-28, in Manchester, UK.

Canadian Government. 2001. Aboriginal peoples of Canada. Statistics Canada. http:// www12.statcan.ca/english/census01/Products/Analytic/companion/abor/canada.cfm.

Canadian Government. 2003. Natural resources Canada. Atlas of Canada. http:// atlas.nrcan.gc.ca/site/english/maps/peopleandsociety/population/Aboriginalpopulation/ abo_1996/subdivision. 
Canadian Government. 2008. Canadian immigration statistics. Canadian Immigration Job Issues. http://www.canadaimmigrants.com/statistics2.asp.

Center for Public Education. 2008. School demographics: What is the ethnic and racial makeup of our schools? National School Board Association. http://www.centerforpubliceducation.org.

Coutinho, M.J., and D.P. Oswald. 2000. Disproportionate representation in special education: A synthesis and recommendations. Journal of Child and Family Studies 9, no. 2: 135-56.

Drilik, A. 1999. Formations of globality and radical politics. The Review of Education/ Pedagogy/Cultural Studies 21, no. 4: 301-38.

Dyson, A., and F. Gallannaugh. 2008. Disproportionality in special needs education in England. Journal of Special Education 42, no. 1: 36-46.

European Roma Rights Centre. 2007a. The ERRC legal strategy to challenge racial segregation and discrimination in Czech schools. Roma Rights Quarterly. European Roma Rights Centre. http://www.ceeol.com/aspx/publicationdetails.

European Roma Rights Centre. 2007b. The impact of legislation and policies on school segregation of Romani children. European Roma Rights Centre. http://www.ceeol.com/ aspx/publicationdetails.

Ferri, B.A., and D.J. Connor. 2005a. In the shadow of Brown: Special education and overrepresentation of students of colour. Remedial and Special Education 26, no. 2: 93-100.

Ferri, B.A., and D.J. Connor. 2005b. Tools of exclusion: Race, disability, and (re)segregated education. Teachers College Record 107, no. 3: 453-74.

Gelb, S.A., and D.T. Mizokawa. 1986. Special education and social structure: The commonality of 'exceptionality'. American Educational Research Journal 23, no. 4: 543-57.

Gibson, M.A., and A.R. Rojas. 2006. Globalization, immigration, and the education of 'new' immigrants in the 21st century. Current Issues in Comparative Education 9, no. 1: $69-76$.

Goldstein, H. 2004. Education for all: The globalisation of learning targets. Comparative Education 40, no. 1: 7-14.

Herrnstein, R.J., and C. Murray. 1994. The bell curve: Intelligence and class structure in American life. New York: Free Press.

Hosp, J.L., and D.J. Reschly. 2004. Disproportionate representation of minority students in special education: Academic, demographic, and economic predictors. Exceptional Children 32, no. 7: 67-80.

Indian and Northern Affairs Canada. 2004. Quality in First Nations education. Indian and Northern Affairs Canada. http://www.ainc-inac.gc.ca/ps/edu/finre/qua_e.html.

Katzenbach de Ramírez, S. 1997. Deutsch Lernen-(K)ein Problem? Sprache und Sprachkompetenz als Instrument der Integration. Bonn: Beauftragte der Bundesregierung für die Belange der Auslander.

Losen, D.J., and G. Orfield, eds. 2002. Racial inequity in special education. Cambridge, MA: Harvard Publishing Group.

MacMillan, D.L., and D.J. Reschly. 1998. Overrepresentation of minority students: The case for greater specificity of the variables examined. The Journal of Special Education 32: 1524.

Massey University. 2000. Executive summary, special education 2000. Massey University. http://specialeducation-research.massey.ac.nz/Reports/reportsphase2/Chap1.pdf.

Matheson, J. 2006. A report on New Zealand student engagement 2005. Government of New Zealand. http://www.educationcounts.govt.nz/publications/series/2303/3557.

Mattson, L., and L. Caffrey. 2001. Barriers to equal education for aboriginal learners: A review of the literature. Vancouver: British Columbia Human Rights Commission.

McBride, S.R., and W. McKee. 2001. Over-representation of aboriginal students reported with behaviour disorders: A report to the Ministry of Education-British Columbia. McBride Management Ltd. http://www.bced.gov.bc.ca/abed/abed_over.pdf.

Ministry of Education, Province of British Columbia. 2001. How are we doing? An overview of aboriginal education results for province of BC 2001. British Columbia Ministry of Education. http://www.bced.gov.bc.ca/abed/results.pdf.

Ministry of Education, Province of British Columbia. 2002. How are we doing? Demographics and performance of aboriginal students in BC public schools. Vancouver: British Columbia Ministry of Education. 
Minority Rights Group International. 2006. State of the world's minorities 2007: Events of 2006. London: Minority Rights Group International.

Minow, M. 1990. Making all the difference: Inclusion, exclusion and American law. Ithaca, NY: Cornell University Press.

New Zealand Council for Educational Research. 2000. Schools must reach out to Māori parents for students to succeed. Inside 31, no. 2: 1. http://www.nzcer.org.nz/pdfs/ ResearchedSep.pdf.

New Zealand Department of Labour. 2008. Migration trends 2006/7. Government of New Zealand. http://www.immigration.govt.nz/NR/rdonlyres/814ACAD1-743B-4B8E-A4FBA2B492360FFD/0/MigrationTrends200607.pdf.

New Zealand Ministry of Education. 1995. Special education policy guidelines. Wellington: Ministry of Education.

New Zealand Ministry of Education. 2003. Student numbers as at 1 July 2003. Government of New Zealand. http://www.educationcounts.govt.nz/statistics/schooling/july_school_roll_ returns/6028/student_numbers_as_at_1_july_2003.

New Zealand Ministry of Education. 2006. State of education in New Zealand: 2006. Government of New Zealand. http://www.educationcounts.edcentre.govt.nz/publications/ece/ state_of_education_in_new_zealand_2006.

New Zealand Ministry of Health. 2004. Living with disability in New Zealand. Government of New Zealand. http://www.moh.govt.nz/moh.nsf/0/35c56e093758b96fcc256f320007bd fb? OpenDocument.

Open Society Institute. 2005. Equal access to quality education for Roma. Summary 1 of the EU Monitoring and Advocacy Program of the Open Society Institute. New York: Open Society Institute.

Organisation for Economic Co-operation and Development (OECD). 2004. Equity in education. Students with disabilities, learning difficulties and disadvantages. Paris: OECD.

Papastephanou, M. 2005. Globalisation, globalism and cosmopolitanism as an educational ideal. Educational Philosophy and Theory 37, no. 4: 533-51.

Pearl, A. 1997. Cultural and accumulated environmental deficit models. In The evolution of deficit thinking: Educational thought and practice, ed. R.R. Valencia, 132-59. Bristol: Falmer, Taylor \& Francis.

Peters, S.J. 2004. Inclusive education: An EFA strategy for all children. Washington, DC: World Bank.

Powell, J.J.W. 2006. Special education and the risk of becoming less educated. European Societies 8, no. 4: 577-99.

Powell, J.J.W. 2009. To segregate or to separate? The institutionalization of special education in the United States and Germany. Comparative Education Review 53, no. 2: 161-87.

Silver, J., K. Mallett, J. Greene, and F. Simard. 2002. Aboriginal education in Winnipeg inner city high schools. Canadian Centre for Policy Alternatives. http://ius.uwinnipeg.ca/pdf/ Aboriginal-education.pdf.

Skiba, R., A. Simmons, S. Ritter, K. Kohler, M. Henderson and T. Wu. 2006. The context of minority disproportionality: Practitioner perspectives on special education referral. Teachers College Record 108, no. 7: 1424-59.

Söhn, J. 2008. Bildungsunterschiede zwischen Migrantengruppen in Deutschland: Schulabschlüsse von Aussiedlern und anderen Migranten der ersten Generation im Vergleich. Berliner Journal für Soziologie 18, no. 3: 401-31.

Statistics New Zealand. 2008. Māori. Government of New Zealand. http://www.stats.govt.nz/ people/communities/maori.htm.

Statistisches Bundesamt. 2001. Bildungsstatistik, Fachserie 11, Reihe 1. Wiesbaden, Germany: Statistisches Bundesamt.

Statistisches Bundesamt. 2002. Bildungsstatistik, Fachserie 11, Reihe 1. Wiesbaden, Germany: Statistisches Bundesamt.

Statistisches Bundesamt. 2004. Bildungsstatistik, Fachserie 11, Reihe 1. Wiesbaden, Germany: Statistisches Bundesamt.

Statistisches Bundesamt. 2005. Bildungsstatistik, Fachserie 11, Reihe 1. Wiesbaden, Germany: Statistisches Bundesamt.

Stewart, W.D. 1993. Immigration and education: The crisis and the opportunities. Lanham, MD: Lexington Books. 
Suarez-Orozco, M.M. 2001. Globalization, immigration, and education: The research agenda. Harvard Educational Review 71, no. 3: 345-65.

Tamatea, L. 2005. The Dakar Framework: Constructing and deconstructing the global neo-liberal matrix. Globalisation, Societies and Education 3, no. 3: 311-34.

UNESCO. 1990. World declaration on education for all. UNESCO. http://www.unesco.org/ education/efa/ed_for_all/background/world_conference_jomtien.shtml.

UNESCO. 1994. Salamanca statement and framework for action on special needs education. UNESCO. http://www.un.org/esa/socdev/enable/disovlf.htm.

UNESCO. 1999. Salamanca five years out. A review of UNESCO activities in the light of the Salamanca statement and framework for action on special needs education. Paris: UNESCO.

UNESCO. 2000. Dakar framework for action. UNESCO. http://unesdoc.unesco.org/images/ 0012/001211/121147e.pdf.

UNESCO. 2002. Education for all: An international strategy to put the Dakar framework for action on education for all into operation. Paris: UNESCO.

United Nations. 2006. International migration 2006. New York: United Nations.

US Census Bureau. 2006a. Hispanic population in the United States. US Census Bureau. http://www.census.gov.

US Census Bureau. 2006b. We the people: American Indians and Alaska Natives in the United States, Census 2000 Special Report. Washington, DC: US Department of Commerce.

US Census Bureau. 2007. The American community: American Indians and Alaska Natives2004, American Community Survey Reports. US Department of Commerce. http:// www.census.gov/prod/2007pubs/acs-07.pdf.

US Department of Education. 2006. Data tables for OSEP state reported data. US Department of Education. https://www.ideadata.org.

US Department of Education. 2007. 27th annual report to Congress on the implementation of the Individuals with disabilities act, 2005, Volume I. Washington, DC: US Department of Education.

US Government. 2007. State Department background notes. Department of State Bureau of Public Affairs. http://www.state.gov/r/pa/ei/bgn/.

Wagner, S.J., and J.J.W. Powell. 2003. Ethnisch-kulturelle Ungleichheit im deutschen Bildungssystem: Zur Überrepräsentanz von Migrantenjugendlichen an Sonderschulen In Wie man behindert wird, ed. G. Cloerkes, 183-208. Heidelberg: Winter.

Wehmeyer, M.L., and M. Schwartz. 2001. Disproportionate representation of males in special education services: Biology, behavior, or bias? Education and Treatment of Children 24, no. 1: 28-45. 